\title{
The Effect of Greenhouse and Biopore on Community Development of Economy and Knowledge of Citeureup Village During the Pandemic
}

\author{
Tania Verasta ${ }^{1}$ \\ ${ }^{1}$ Engineering Physics, School of Electrical Engineering \\ Telkom University, Bandung, Indonesia \\ taniaverasta@student.telkomuniversity.ac.id \\ Ihsan Maulidin², Hapsah Aulia Azzahra ${ }^{3}$, Aulya Sholehah Wataawa Sau Bhis Sobri ${ }^{4}$, \\ Amaliyah Rohsari Indah Utami ${ }^{5^{*}}$ \\ ${ }^{2,3,4,5}$ Engineering Physics, School of Electrical Engineering \\ Telkom University, Bandung, Indonesia \\ ihsanmaudilin@student.telkomuniversity.ac.id, hapsahauliaa@student.telkomuniversity.ac.id, \\ aulyasw@student.telkomuniversity.ac.id, amaliyahriu@telkomuniversity.ac.id
}

(Received May 04, 2021, accepted June 29, 2021)

\begin{abstract}
Citeureup Village, $R W$ 06, located in Bandung Regency, West Java Province, is a regional area with low-level economy. The Covid-19 pandemic has made it worse and adding difficulties to the villagers. On the other hand, this area also often experiences flooding with an erratic pattern. Therefore, efforts are needed to improve local food security, economy, and flood disaster mitigation for the Citeureup Village community. Efforts has been made by Telkom University, some through activities carried out by students of the Undergraduate Program in Engineering Physics (TF), which were to carry out community service activities funded by the Village Development and Empowerment Holistic Program (PHP2D) in 2020. These activities were decided by decree number 29/E2/KM/2020. The results of these activities are the construction of a Hydroponic Greenhouse (HG) on $10 \mathrm{~m} \times 4 \mathrm{~m}$ and biopore infiltration holes as many as 45 hole constructions throughout $R W 06$ Citeureup Village. Three months after construction, HG's existence has succeeded in improving Citeureup Villagers behavior and practical knowledge in hydroponic and biopore systems from $21 \%$ to 98\%. As conclusion, Telkom University has succeeded in playing role in improving knowledge, local food security, economy, and reducing flood inundation at Citereup Village.
\end{abstract}

Keywords: biopore; economy; food security; greenhouse; hydroponics 


\section{Introduction}

Citeureup is a village located in Dayeuhkolot District, Bandung Regency. Following the RUTRK Dayeuhkolot data in 2004, the area of Citeureup Village is 188.73 hectares and has a population of 20,537 people. The area of Citeureup Village is mostly residential land and only a few agricultural and industrial areas, while the majority of Citeureup villagers work as private employees, around 18.84\% (Data Demografi Berdasarkan Pekerjaan, n.d.). Citeureup Village is often referred to as a village which has many problems, both economic and natural problems that don't go away. For example, the main problems that always occur in Citeureup Village are floods, lack of agricultural land, low food security, low economy and lack of clean water availability. Citeureup Village is an area affected by severe flooding in the Dayeuhkolot area. Flood height varies from 10 centimeters to 2 meters (Kusnita, 2020). The next problem, the Citeureup Villagers live in a low economic level, especially when facing the pandemic of Covid-19. This is indicated by the decreasing local food security (Yusuf et al., 2020). The potential of natural resources in the village, apart from still being dependent on the management of agricultural land, also has another potential in the industrial and service sectors. Lack of agricultural land in the village causes the community to rely solely on work as private employees who are limited only to certain groups.

However, the lack of agricultural land is not necessarily true as a benchmark for agricultural activities. There are so many innovations and latest technological developments those can be used in carrying out agricultural activities. Based on the description of the problems above, to improve the economy and local food security level of the Citeureup village community, the construction of a hydroponic house is an indispensable solution (Kelompok Studi Bioenergi dan Bioproduk, 2020). Hydroponic system require less land than traditional agriculture (Hidayat et al., 2020). Therefore, the Hidrobici Team which consists of a student group studying bioenergy and bioproduct in Engineering Physics at Telkom University assisted with the housing development program for hydroponics in RW 6 villages, working together with the community and the campus of Telkom University through PHP2D namely Village Development and Empowerment Holistic Program from the Ministry of Education and Culture of the Republic of Indonesia. The Hidrobici Team carried out a community service program that was held from September 1 to December 31, 2020 (Kelompok Studi Bioenergi dan Bioproduk, 2020). Activities carried out in this program were the construction of hydroponic houses as the center of community activities. The community was taught how to 
make good use of the land by constructing hydroponic systems, seedling, planting and maintaining plants, and organizing the results of hydroponic plants so that they can improve food producing and the community's economy.

A hydroponic greenhouse is a building that functions as a place for cultivating horticultural crops with a hydroponic farming system. Agricultural land problems in Citeureup Village can be resolved by building a hydroponic house. Hydroponics is a method of farming without using soil media, but with nutritious mineral solutions or other materials. Soil substitutes must contain nutrients such as coconut husk, mineral fiber, sand, broken bricks, sawdust, and others (Chandra, 2016). Hydroponic cultivation can develop quickly because this method has many advantages. The main advantage is that plants can grow and produce better than ordinary planting techniques (M.K., 2015). Meanwhile, if you use conventional techniques, you need a large area for planting, the use of pesticides that can damage environmental sustainability, and the harvest period for conventional is longer than hydroponics (Ariati et al., 2018).

On the other hand, to solve the problem of flooding that always occurs in Citeureup Village, Hidrobici Team provided a solution in the form of biopore infiltration hole construction, which covered most of RW 06 area, at Citeureup Village. With the presence of biopore infiltration holes, water absorption can be accelerated (Ichsan \& Hulalata, 2018). When this happens, there is no longer standing water around the residential houses.

As a side effect of the community service activities, the level of public awareness in the importance of knowledge about hydroponic house construction and about biopore infiltration hole construction increases. With the construction of hydroponic houses, the community gets several benefits. The community can save for every harvest process they get. For food security, the community can save a few percent more compared to before the hydroponic house construction. Besides, the community can improve the flood disaster mitigation effort in Citeureup Village. This have a positive impact on the improvement of knowledge for every household in the Citeureup Village and could extend to their neighborhoods and hopefully to other villages beyond. 


\section{Methods}

The method used in this community service program is the qualitative method. With this method, primary and secondary data were obtained through direct visits to the village (survey), open interviews, questionnaires, and literature studies for a period of 4 months by the Hidrobici Team to the community of Citeureup Village RW 06. Citeureup Village community empowerment was implemented with a mixed methods or combination system. This was carried out in consideration of red zones that exists in the region of Jawa Barat.

\section{Sources of Data}

In this paper, the data source was taken as primary data, because data was collected directly through field study and direct interviews to the people targeted, community of PKK and Karang Taruna RW 06 Citeureup Village. The activities can be seen in Figure 1.

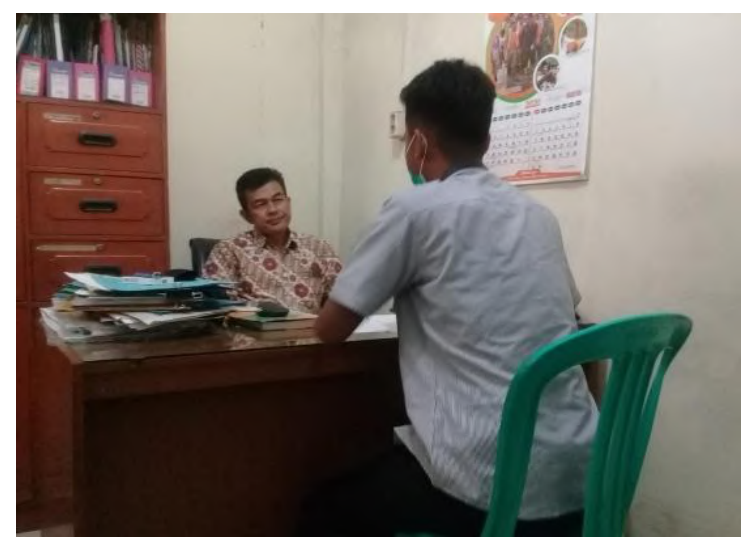

(a)

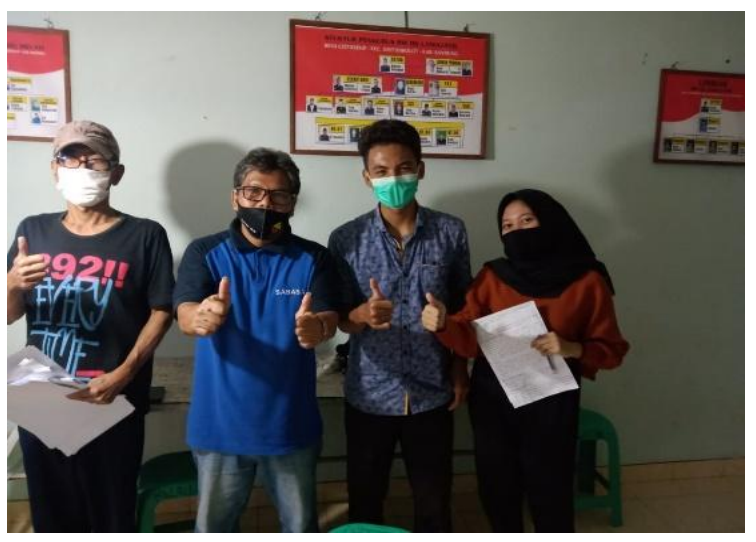

(b)

Fig. 1. Field study by Hidrobici Team at Citeureup Village RW 06 (a) discussion group directed by RW and RT 06 Citeureup Village (b) permission to conduct field research from the head of Citeureup Village

\section{Analysis Data Methods}

\section{Direct Visit to Citeureup Village (Survey)}

The Team Hidrobici identified problems that would hamper the implementation of the development program and analyzed the needs and prerequisites to hydroponic cultivation program to grow plants and vegetables suitable for the Citeureup Village. After discussion, planning determined for activities in empowering the community of the village to build hydroponic greenhouse and biopore infiltration hole construction.

After the program had been agreed upon, the team asked for formal approval from the head of the village and the head of RW and RT of Citeureup Village. Dissemination of information 
was held to introduce the program to the Citeureup Village community regarding the hydroponic greenhouse and biopore construction. So that the public can understand the benefits and the purpose of the program. Thus, residents were expected to be more active and able to contribute to activities.

\section{Open interviews with the community of Citeureup Village RW 06}

Methods of field study carried out was by observing the development and the improvement of field condition of Citeureup Village RW 06 as target, both before and after the activities of PHP2D 2020, and interviewing the people targeted by the program (groups of Hydroponics Farmer of Citeureup Village). Study findings by Hidrobibi Tea, before the PHP2D program, the target community experienced quite high economic problems, especially during the pandemic. The target community consisted of 20 people, and only 5 of them who still have a job, while the rest experienced layoffs. This economic situation had major impact on their ability to meet their food needs. Data shown that there was an increase in the price of a bunch of pokcoy vegetables while before the pandemic, the price was Rp. 3,000/tie. However, after the emergence of the pandemic, the price was increased to Rp. 5,000/tie.

On the other hand, flood was another major issue that faced by the villagers. At the moment when the Hidrobici Team conducted field study, most of the street at the village had pools of water because the drainage clogged by garbage. The river nearby of the village experienced a rise in volume quite high. Thus, villagers were worried that rainwater would flood when high rate of rainfall happened in one day.

Based on literature study, problems found from the field observation at the village led to the need for implementation of hydroponic greenhouses as solution for improving the local food security and villagers economy development, while implementation of biopore infiltration hole construction can be solution for catastrophic flood mitigation.

Based on the interview result after the program, it was found that the villagers could meet their need of food from the hydroponic crops yield. Thus, it has an impact to the economy of the target community. Villagers do not need to expend more to buy vegetables whenever prices soared high. The presence of biopore holes accelerates the absorption of rainwater and excess water would no longer stagnate as pool of water on the streets. 


\section{Questionnaire}

To find out if there is an increase in the knowledge and behavior of the target villagers in the use of hydroponic greenhouses and biopore infiltration holes, the Hidrobici Team conducted a survey in the form of a questionnaire.

\section{Literature Study}

From the literature study, the Hidrobici Team collected several journals and books about the issues that were being discussed such as the scientific articles about system and steps in planting hydroponic crops.

The data analysis conducted was the quantitative descriptive analysis method, which is intended to discuss problems by describing the form of program implementation, in the form of images, or the form of documentation.

\section{Results And Discussion}

\section{Survey Result}

The program implementation process was conducted for 4 months from September to December 2020. Based on the survey result, the team obtained vacant land suitable for hydroponic greenhouse and biopore construction. Furthermore, the team was forming Hydroponic Farmer Group from the Citeureup Village community.

\section{a. Hydroponic Greenhouse Development}

Figure 2 shows the conditions of an empty land of $22 \mathrm{~m}^{2}$, which was originally a dumping ground for mud and garbage due to flooding. This land later used as a place for the construction of a hydroponic greenhouse.

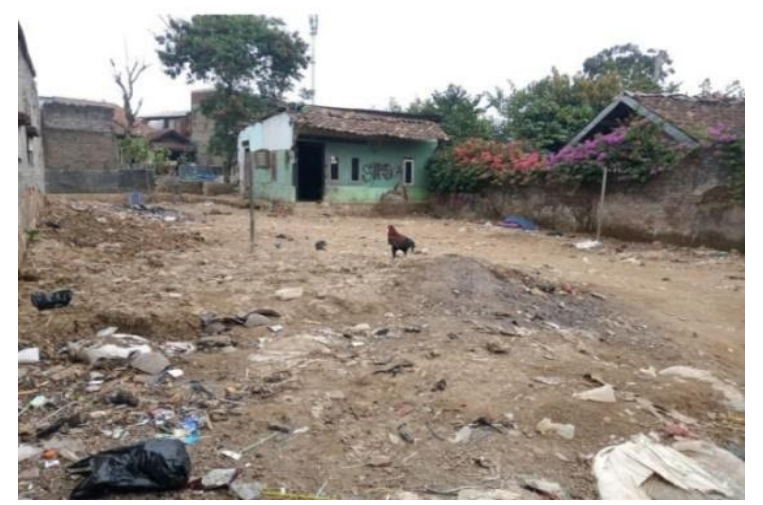

Fig. 2. Land conditions before the hydroponic greenhouse development took place 
Based on the literature study, the author found the solution to the problem of land in the Citereup Village that can be solved through agricultural hydroponics. Farming in hydroponics has many advantages, such as plant can grow and produce much better and faster compared to the technique of planting normally, easier and more practical pest control, the use of less (sparingly) fertilizers, plants that die out will be easier to replace with new plants and require less energy compared to the conventional plantation (Chandra, 2016).

The first step in processing the vacant land was measuring the size of land. The vacant land then be made into two hydroponic greenhouses. Each greenhouse filled with four tables where the Wick hydroponic system was put into and also two NFT hydroponics systems on each side of the greenhouse. The data about land and hydroponic structure plan are shown in the following table:

Table 1. Land data from hydroponic observation and planning

\begin{tabular}{lc}
\hline Land Area & $22 \mathrm{~m}^{2}$ \\
\hline The length of the hydroponic greenhouse & $10 \mathrm{~m}$ \\
\hline The width of the hydroponic greenhouse & $4 \mathrm{~m}$ \\
\hline Height of hydroponic greenhouse & $5 \mathrm{~m}$ \\
\hline The length of the table where the hydroponic system is located & $1 \mathrm{~m}$ \\
\hline The width of the table where the hydroponic system is located & $3 \mathrm{~m}$ \\
\hline
\end{tabular}

After 3 months of survey and development, the vacant land was established as can be seen in Figure 3. The vacant land consisted of two hydroponics greenhouses with each greenhouse had two types of hydroponics systems which are system Wick and NFT. At the hydroponic greenhouse vicinity, the villagers was provided with knowledge about how to plant and maintain hydroponic plants in advance. Thus, those persons already made to understand how to take care of hydroponic plants properly and correctly. Example is in examining and providing nutrition with a TDS measuring instrument. The knowledge provided can be accepted and practiced by the community in real-time. Through the intensive care stage by the community with supervision by the team for one month, the 
yield of hydroponic plants were ready to be harvested by the community. The first harvest was done with the community and distributed to 44 households.

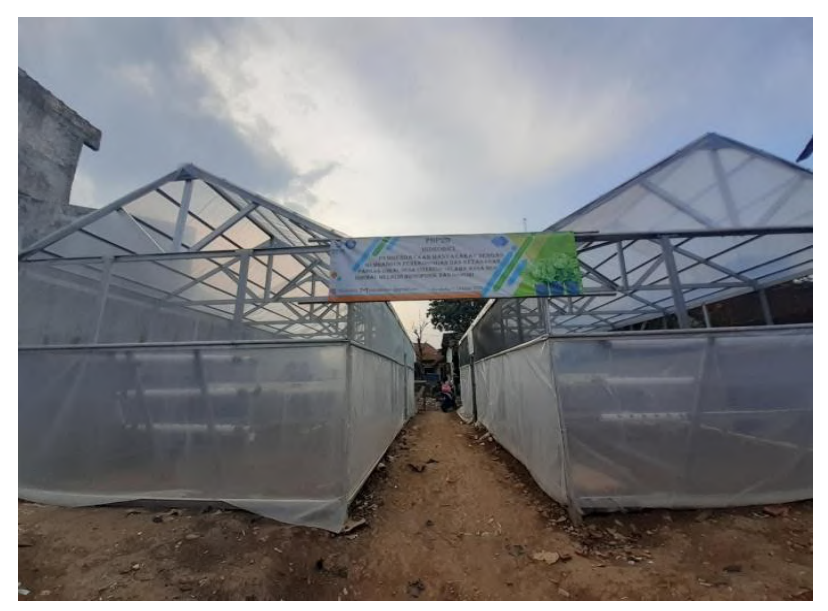

Fig. 3. Results of 3 months of greenhouse development by the Hidrobici PHP2D Team 2020 with the Citeureup Village community

\section{b. The Construction of Biopore Infiltration Holes}

For the biopore infiltration hole construction, Hidrobici Team carried out field survey in RW 06 Citeureup Village, to find a suitable place that can absorb floodwater easily. Based on the survey, several locations were suitable as biopore sites (the distribution of places and the number of biopores can be seen in Table 2). Each biopore has $1 \mathrm{~m}$ depth. The team did the biopore construction together with the villagers as seen in Figure 4.

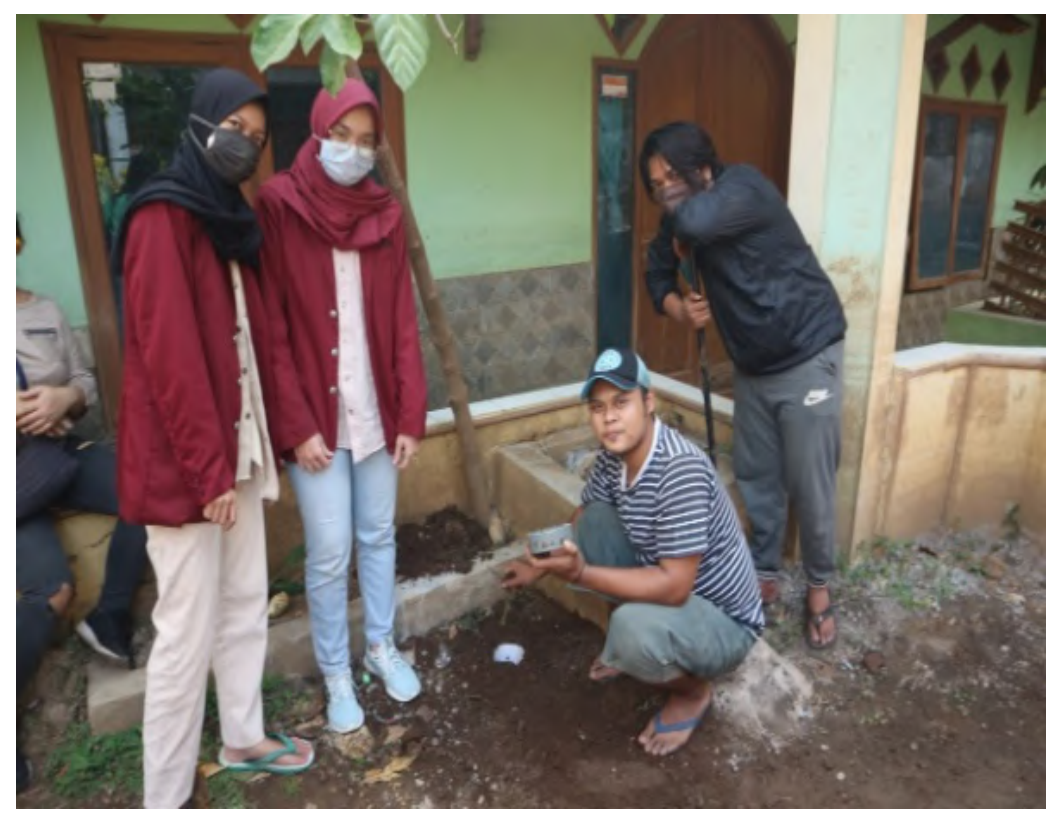

Fig. 4. Planting biopore by Hidrobici Team along with villagers at a house in RW 06 
Table 2. Distribution of biopore infiltration holes in RW 06 Citeureup Village

\begin{tabular}{ll}
\hline Around the hydroponic greenhouse & 4 biopore holes \\
\hline Weather house of RW 06 & 6 biopore holes \\
\hline Field near the houses of RW 06 & 2 biopore holes \\
\hline Home yard of the residents of RT 01 & 4 biopore holes \\
\hline Home yard of head of RT 02 & 1 biopore hole \\
\hline The empty home yard of RT 02 & 4 biopore holes \\
\hline The empty home yard of RT 04 & 3 biopore holes \\
\hline Home yard of the residents of RT 04 & 5 biopore holes \\
\hline Home yard of the residents of RT 05 & 11 biopore holes \\
\hline Vacant land in RT 03 & 5 biopore holes \\
\hline
\end{tabular}

\section{Increased Public Knowledge}

The empowerment program for the community in the form of hydroponic greenhouse development and biopore construction in RW 06 Citeureup Village resulted in the change of behavior in the community, in this case, the improvement in community knowledge from $21 \%$ to $98 \%$ about hydroponics agriculture and biopore systems. These results were obtained from questionnaire that was given to 60 participants from the target community.

\section{a. Hydroponics}

The improvement of community knowledge in RW 06 Citeureup Village about hydroponics can be seen in Figure 5. Before the program, only 31 people knew about the hydroponic system and after the program, 60 people knew about the hydroponic farming system. Hence, with this knowledge, the people from RW 06 Citeureup Village will be able to build and take care of their hydroponic independently. 


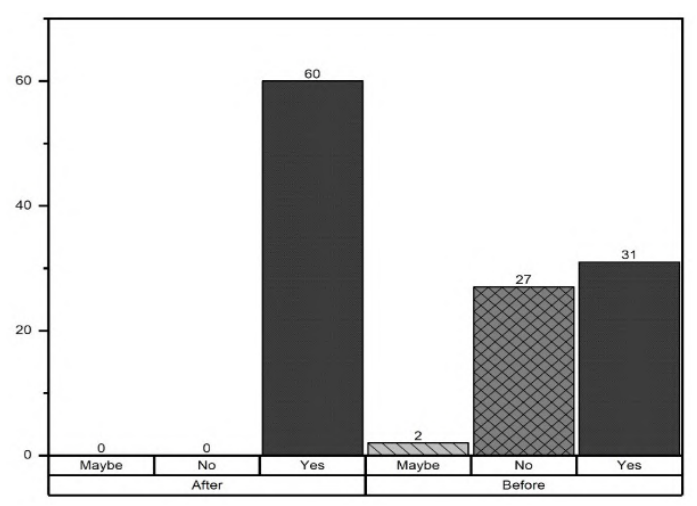

Fig. 5 Community knowledge about hydroponics before and after PHP2D 2020

\section{b. Biopore}

From Figure 6 we could see the improvement of community knowledge about biopore. Before the program, only 29 people knew about the biopore infiltration holes and after the program, 60 people knew about the biopore infiltration hole system. With the improvement of knowledge about biopore, people from Citeureup Village will be able to construct biopore as needed in the future.

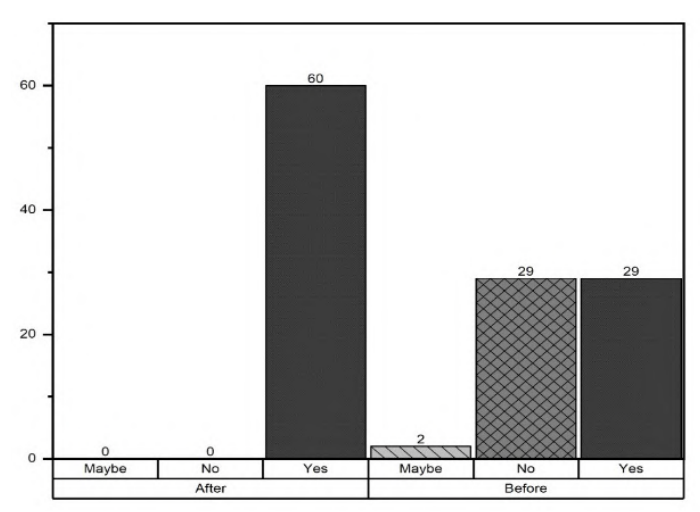

Fig. 6. Community knowledge about biopore infiltration holes before and after PHP2D 2020

The construction of biopore infiltration holes in RW 06 Citeureup Village results in the improvement of catastrophic flooding mitigation. With the existence of biopore infiltration holes, the condition of the village that previously was always inundated with high water after the rain, now it has shown less pool of water significantly after rain because rainwater absorbed by the biopore hole as can be seen in Figure 7. 


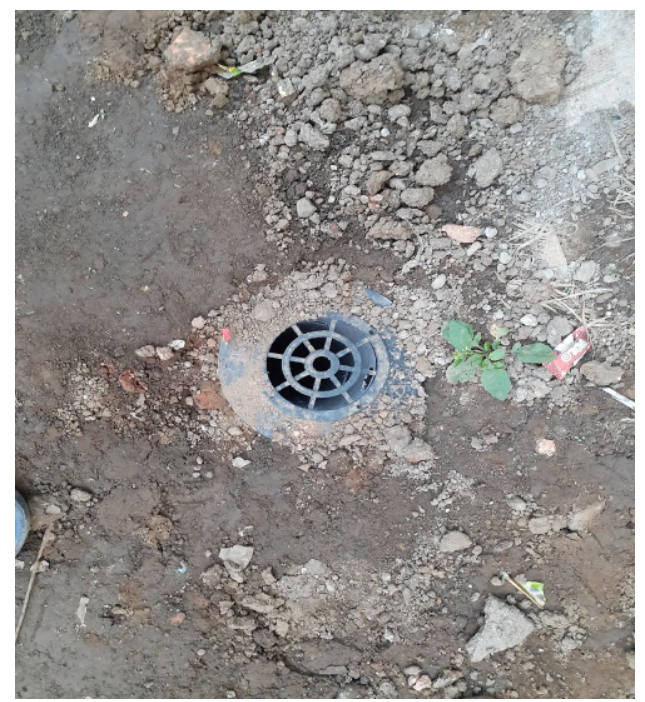

Fig. 7. Shape of biopore infiltration hole in RW 06 Citeureup Village

The improvement of knowledge about hydroponic and biopore influences community behavior. With this program, people become aware of being productive by farming hydroponically and aware of the importance of biopore to reduce floods. The Hidrobici Team helped the community to learn about hydroponic and biopore so that the community not only aware but also prepared with knowledge and have desire to develop their abilities related to hydroponics cultivation independently. The RW 06 in Citeureup Village community can help themselves in food resilience, economic development, and to do flood mitigation. This behavior shows that the community of RW 06 in Citeureup Village is empowered (Aristianto, 2018).

\section{Economy}

Figure 8 shows the hydroponic yield data for the last three months where the total yield obtained was $19.5 \mathrm{~kg}$. These data indicate that each month the resulting hydroponic yields were increasing. This happened because planting was done by paying attention to the harvest period and the growing period of the vegetables. More vegetables that have a fast-growing period such as kale, 2 weeks harvest-time, are planted. The harvested food was used for food security for the family affected by the pandemic in RW 06 Citeureup Village. 


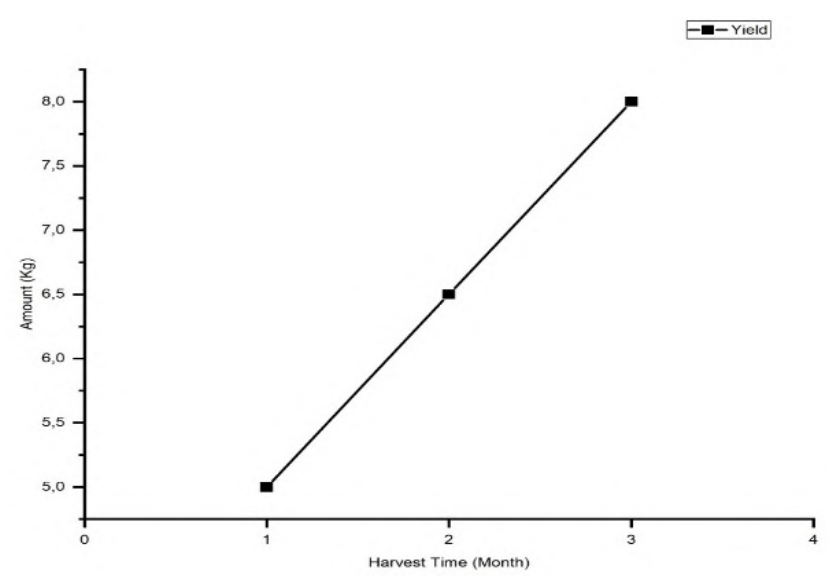

Fig. 8. Increasing yield of hydroponics greenhouse in Citeureup Village

Besides being able to establish food security, the results of this program also make people spend less on expenses. In the first harvest, each family in RW 06 accepted 5 belts, equals to about $0.25 \mathrm{~kg}$ of various vegetables, such as spinach, kale, pokcoy, per day. Each bunch of vegetables was sold at an average price of Rp. 5,000 per bunch, therefore people can save as much as Rp. 25,000 per day. Based on data obtained from 44 families who became the first program target, before the hydroponic cultivation program, they approximately spent Rp. 35,000 per day and only $25 \%$ of these 44 families could fulfil themselves their everyday food by doing plantation in their own house. After the program, the Hidrobici Team increased the total household that could fulfil their own everyday food requirement from $25 \%$ to $71 \%$. The total amount of money saved each day is Rp. 25,000 .

\section{Sustainability Results}

The hydroponic greenhouse development program as a medium for improving local food security and economy, and planting biopore infiltration holes in Citeureup Village, especially in RW 06 which that has been implemented is a program that can be continually developed with various innovations. The next plan is development program by adding a catfish pond with catfish excrement management to be used as hydroponic plant nutrients. And also, catfish is another source of nutrients that can be consumed to meet the needs of the community's livestock resources. So, with improvement in knowledge of the people of Citeureup Village, especially RW 06, it can become a village that has strong livestock and vegetable food security. Although some mentoring support from students, lecturers, and the academic community of Telkom University are still in order. 


\section{Conclusion}

The Hidrobici Team has successfully built hydroponic greenhouse at a land area of $10 \mathrm{~m} \times 4 \mathrm{~m}$ and constructed biopore infiltration hole as many as 45 holes in RW 06 Citeureup Village. With the factor of collaboration between the target community and students to run the program in development of hydroponics greenhouse has succeeded in improving the behavior of target community. Knowledge about the hydroponics system and biopore improved from $21 \%$ to $98 \%$. The improvement of knowledge, managed to help Citeureup Villagers to improve the resilience of food security locally from $20 \%$ to $80 \%$, and the economy of the community improved from $25 \%$ to $71 \%$ during the pandemic. On the other hand, the program succeeded in helping to improve flood mitigation in Citeureup Village. To increase the yield of local food security and improving the economy, it is recommended every home residents of Citeureup Village has own hydroponics and biopore construction. It is also recommended to concern about planting and harvesting calendar. In addition, as a form of sustainability programs in local food security for Citeureup Village, next program can be expanded on the adequacy of animal protein intake for the community. Hydroponics greenhouse can be applied as combination with aquaponics catfish, and this also provided a marketplace for rural communities. Program sustainability can be maintained through collaboration between the community of Citeureup Village RW 06, Engineering Physics Students, and the Academic Community of Telkom University.

\section{Acknowledgments}

The authors would like to thank the Ministry of Education and Culture of the Republic of Indonesia (via decree no. 29/E2/KM/2020) which has provided funding and support for the activities of Village Development and Empowerment Holistic Program (PHP2D) conducted by Hidrobici Team. The authors would also like to thank the Bioenergy and Bio Products Laboratory study group for providing laboratory facilities. Also thankyou to Engineering Physics of Telkom University. Thankyou to the student affairs of the School of Electrical Engineering Telkom University who provide facilities and support, so that the author can complete this paper. Thankyou to RW 06 Citeureup Village as a partner in community empowerment activities by involvement in building the economy and local food security in Citeureup Village during New Normal through hydroponics greenhouse and biopores construction. 


\section{References}

Ariati, P. E. P., Atmaja, N. P. C. D., \& Utami, N. M. S. (2018). Abdimas Hidroponik sebagai Basis Peningkatan Perekonomian Masyarakat pada PKK Banjar Delod Pangkung Desa Sukawati, Kecamatan Sukawati Kabupaten Gianyar. 07(01).

Aristianto, A. (2018). Pemberdayaan Keluarga Lansia Melalui Usaha Ekonomi Produktif oleh Bina Keluarga Lansia Ayah Bunda Ceria Kelurahan Tanaman Tulungagung Perspektif Ekonomi Islam. Institut Agama Islam Negeri Tulungagung.

Chandra, W. (2016). Hidroponik, Solusi Pertanian Lahan Sempit di Perkotaan_ Mongabay. https://www.mongabay.co.id/2016/09/17/hidroponik-solusi-pertanian-lahan-sempit-diperkotaan/

Data Demografi Berdasarkan Pekerjaan. (n.d.). WEBSITE RESMI DESA CITEUREUP. Retrieved August 7, 2020, from https://www.citeureup-bandung.desa.id/first/statistik/1 Hidayat, S., Satria, Y., \& Laila, N. (2020). Penerapan Model Hidroponik Sebagai Upaya Penghematan Lahan Tanam Di Desa babadan kecamatan Ngajum kabupaten Malang. $\begin{array}{llll}\text { Jurnal Graha } & \text { Pengabdian, } & \text { 141-148. }\end{array}$ http://journal2.um.ac.id/index.php/jgp/article/view/13346

Ichsan, I., \& Hulalata, Z. S. (2018). Analisa Penerapan Resapan Biopori Pada Kawasan Rawan Banjir Di Kecamatan Telaga Biru. Gorontalo Journal of Infrastructure and Science Engineering, 1(1), 33. https://doi.org/10.32662/gojise.v1i1.139

Kelompok Studi Bioenergi dan Bioproduk. (2020). Pembinaan dan Pemberdayaan Desa Citeureup dengan Membangun Perekonomian dan Ketahanan Pangan Lokal Selama Masa New Normal melalui Hidroponik dan Biopori. Universitas Telkom.

Kusnita, G. (2020). PENANGANAN BANJIR DAYEUHKOLOT. WEBSITE RESMI DESA CITEUREUP. https://www.citeureup-bandung.desa.id/artikel/2020/1/26/penangananbanjir-dayeuhkolot

M.K., A. (2015). Kelebihan dan Kekurangan Bercocok Tanam Hidroponik. Dkp3. https://distan.sukabumikota.go.id/kelebihan-dan-kekurangan-bercocok-tanamhidroponik/

Yusuf, A. A., Suganda, T., Hermanto, Mansur, F., \& Hadisoemarto, P. (2020). Strategi Ekonomi Sektor Pertanian di Tengah Pandemi Covid-19. Perspektif 2030: SDGs Center Unpad. http://sdgcenter.unpad.ac.id/strategi-ekonomi-sektor-pertanian-di-tengahpandemi-covid-19/ 